\title{
Avaliação da membrana de quitosana, esterelizada com óxido de etileno ou radiação ultravioleta, na cicatrização de feridas cirúrgicas em equinos
}

Vinicius Marques Rollim;, Gustavo Morandini Reginato, Letícia Martins Fernandes, Luci Cristina de Oliveira Vercik, Eliana Cristina da Silva Rigo, Silvio Henrique de Freitas, Renata Gebara Sampaio Dória

\section{Resumo}

Infecções de feridas cirúrgicas e complicações incisionais podem resultar em aumento dos cuidados pós-operatórios, reintervenções cirúrgicas para reparação de hérnia e morte do animal. Visando evitar tais problemas, este estudo avaliou o emprego de um biomaterial, a quitosana, na cicatrização de feridas cirúrgicas de equinos. Sua utilização é baseada em propriedades como biocompatibilidade, bioadesividade e atuação na abertura das junções epiteliais, possuindo ainda ação antimicrobiana, atividade homeostática, capacidade de ativar macrófagos, estimular a migração e proliferação celular, promover a formação de tecido de granulação, além de orientação a reorganização da histoarquitetura celular em feridas. Este estudo avaliou o comportamento de membranas de quitosana esterilizada com óxido de etileno ou radiação ultravioleta, implantadas no tecido subcutâneo da fossa paralombar esquerda (flanco direito) de equinos, por meio da observação da sua capacidade de auxiliar na cicatrização de feridas cirúrgicas, evitando infecções e ou deiscência de sutura, e observando, também, possível rejeição do material implantado. Foram realizados os procedimentos experimentais em quatro equinos, sendo que cada animal recebeu uma membrana, de forma aleatória, podendo ser de quitosana esterilizada com óxido de etileno ou de quitosana esterilizada com radiação ultravioleta, totalizando duas membranas de cada grupo experimental, que seriam avaliadas durante 15 dias. Após preparo cirúrgico, sedação e anestesia local, foi realizada incisão de $10 \mathrm{~cm}$ de pele e divulsão romba do tecido subcutâneo. Ao mesmo tempo, as membranas de quitosana, estéreis em óxido de etileno ou estéreis em radiação ultravioleta, foram retiradas das placas de petri e submersas em solução fisiológica $0,9 \%$, até que ficassem maleáveis (hidratadas). As membranas de quitosana, com dimensões de $90 \times 15 \mathrm{~mm}$, foram posicionadas na região subcutânea, sobre a fáscia do músculo oblíquo abdominal externo. A pele foi suturada com fio de poliamida (náilon), 0,60 mm, com 7 pontos simples separados. Após o procedimento cirúrgico, os equinos receberam penicilina benzatina, $20.000 \mathrm{UI} / \mathrm{kg}$, a cada 48 horas e 
flunixim meglumine, $1 \mathrm{mg} / \mathrm{kg}$, a cada 24 horas, três aplicações. Os equinos foram avaliados com exame clínico geral pré-cirúrgico, imediatamente após a cirurgia e nos dias 1, 2, 3, 7, 15 de pós-operatório. Os exames consistiram da avaliação da coloração de mucosas, tempo de reperfusão capilar, auscultação da frequência cardíaca, frequência respiratória, motilidade intestinal e aferição da temperatura retal, avaliação externa da ferida cirúrgica, avaliação ultrassonográfica e avaliação de hemograma. Como resultados, não foram observadas alterações clínicas ou hematológicas que identificassem quaisquer repercussões sistêmicas. $\mathrm{Na}$ avaliação externa da ferida cirúrgica, observou-se, a partir do primeiro dia após a implantação das membranas de quitosana, que todos os quatro animais apresentaram sensibilidade ao toque e aumento de volume local, circunscrevendo o local de implantação das membranas, sugerindo início de reação ao implante. Este aumento de volume local permaneceu, desenhando na pele o formato circular da membrana de quitosana implantada. Na avaliação ultrassonográfica, a partir do procedimento cirúrgico, foi observada rejeição do material implantado. Todos os animais expulsaram os implantes, íntegros ou em pedaços, por meio de sinus formado na linha de sutura, até 15 dias de pós-operatório. Verificou-se, então, que houve resposta dos animais contrária aos implantes de quitosana, seja com esterilização por óxido de etileno ou esterilização por radiação ultravioleta, demonstrando que o implante, na composição em que se apresentam, e mesmo com diferença de esterilização, sugere que não tem condições de serem utilizados como auxiliares na cicatrização de feridas.

Palavras-chave: Pós-operatório. Manejo de ferida. Implante. 